\title{
Ghrelin differentially modulates glucose-induced insulin secretion according to feeding status in sheep
}

\author{
Hideyuki Takahashi, Yohei Kurose, Muneyuki Sakaida, Yoshihiro Suzuki, Shigeki Kobayashi, \\ Toshihisa Sugino1, Masayasu Kojima², Kenji Kangawa², Yoshihisa Hasegawa and Yoshiaki Terashima \\ School of Veterinary Medicine and Animal Science, Kitasato University, Towada-shi, Aomori 034-8628, Japan \\ ${ }^{1}$ Graduate School of Biosphere Science, Hiroshima University, Higashi-Hiroshima-shi, Hiroshima 739-8528, Japan \\ ${ }^{2}$ National Cardiovascular Center Research Institute, Osaka 565-8565, Japan \\ (Correspondence should be addressed to Y Kurose; Email: kurose@vmas.kitasato-u.ac.jp) \\ (M Kojima is currently at the School of Veterinary Medicine and Animal Science, Kitasato University, Towada-Shi, Aamori 034-8628, Japan)
}

\begin{abstract}
The present study was conducted to investigate roles of ghrelin in glucose-induced insulin secretion in fasting- and meal-fed state in sheep. Castrated Suffolk rams were fed a maintenance diet of alfalfa hay cubes once a day. Hyperglycemic clamp (HGC) was carried out to examine glucoseinduced insulin response from 48 to $53 \mathrm{~h}$ (fasting state) and from 3 to $8 \mathrm{~h}$ (meal-fed state) after feeding in Experiment 1 and 2 respectively. Total dose of $70 \mathrm{nmol} / \mathrm{kg}$ body weight of D-Lys3-GHRP6, a GH secretagogue receptor 1a (GHS-R1a) antagonist, was intravenously administered at 0,60 , and $120 \mathrm{~min}$ after the commencement of HGC. In the fasting
\end{abstract}

state, the ghrelin antagonist significantly $(P<0 \cdot 01)$ enhanced glucose-induced insulin secretion. In the meal-fed state, i.v. administration of synthetic ovine ghrelin $(0.04 \mu \mathrm{g} / \mathrm{kg}$ body weight per min during HGC) significantly $(P<0 \cdot 05)$ enhanced glucose-induced insulin secretion. D-Lys3GHRP6 treatment suppressed ghrelin-induced enhancement of the insulin secretion. In conclusion, ghrelin has an inhibitory and stimulatory role in glucose-induced insulin secretion via GHS-R1a in fasting- and meal-fed state respectively.

Journal of Endocrinology (2007) 194, 621-625

\section{Introduction}

Ghrelin is a novel peptide that acts on the growth hormone secretagogue receptor (GHS-R) in the pituitary and hypothalamus to stimulate GH secretion (Kojima et al. 1999, Takaya et al. 2000). In some species, there is evidence that ghrelin also stimulates food intake and reduces energy expenditure (Tschop et al. 2000, Nakazato et al. 2001, Wren et al. 2001).

Apart from these actions in the brain, ghrelin has been reported to have a dual role in the regulation of pancreatic insulin secretion. Some studies in rats show that ghrelin stimulates insulin secretion in vivo (Lee et al. 2002) and in vitro (Date et al. 2002, Adeghate \& Ponery 2002). Others show that ghrelin inhibits insulin secretion from rat pancreatic islets in a dose- and glucose-dependent manner (Colombo et al. 2003) and from mouse islets in the presence of glucose (Reimer $e t$ al. 2003). GHS-R antagonist and immunoneutralization of endogenous ghrelin enhance glucose-induced insulin release from perfused rat pancreas (Dezaki et al. 2006). In humans, ghrelin has been shown to cause hyperglycemia by reducing insulin secretion (Broglio et al. 2001). These discrepancies among the effects of ghrelin on insulin secretion have not been examined.
On the other hand, blood ghrelin levels are affected by nutritional states. Plasma ghrelin levels are increased after fasting and reduced after feeding in humans (Ariyasu et al. 2001, Cummings et al. 2001, Shiiya et al. 2002). Lee et al. (2002) showed that a high-fat diet decreases plasma ghrelin levels, whereas a low-protein diet increases plasma ghrelin levels in rats. Therefore, ghrelin secretion may be enhanced under negative energy balance but inhibited under positive energy balance.

Overall, it appears that ghrelin may play an important role in glucose metabolism, through modulation of insulin secretion, but this could be dependent on whether the organisms are in negative or positive energy balance. We observed that plasma levels of ghrelin were inversely related with those of insulin around feeding in sheep (unpublished data). Furthermore, we have demonstrated that ghrelin infusion stimulates glucose-induced insulin secretion in meal-fed sheep (Takahashi et al. 2006). These observations led us to hypothesize that ghrelin regulates insulin secretion dependent on energy balance. In the present study, we have explored this hypothesis by examining the involvement of GHS-R1a in glucose-induced insulin secretion in fastingand meal-fed sheep. 


\section{Materials and Methods}

\section{Experimental animals and treatments}

Twenty two-year-old neonatally castrated Suffolk rams of $51 \cdot 4 \pm 0.3 \mathrm{~kg}$ were placed in metabolism cages and held at $20^{\circ} \mathrm{C}$ ambient temperature under a $12 \mathrm{~h}$ light: $12 \mathrm{~h}$ darkness cycle (0730-1930 h light:1930-0730 h darkness). The animals were fed a maintenance diet of alfalfa hay cubes at $0900 \mathrm{~h}$ each day for 10 days prior to the experimental period, with free access to water. Bilateral jugular venous cannulas were inserted one day prior to the experimentation and closed with two-way taps and filled with heparinized $(40 \mathrm{U} / \mathrm{ml})$ normal saline for infusion and blood sampling. The animals were divided into two groups $(n=4$ per group) in Experiment 1 and into three groups $(n=4$ per group) in Experiment 2.

In Experiment 1, hyperglycemic clamp (HGC; see below) was conducted in both groups from 48 to $53 \mathrm{~h}$ after the last feeding (fasting state), when plasma ghrelin levels reached plateau (Sugino et al. 2002). Ghrelin antagonist-treated group received a total dose of $70 \mathrm{nmol} / \mathrm{kg}$ body weight D-Lys3GHRP-6 (Sigma) in normal saline via the right jugular cannula every $60 \mathrm{~min}$ from 0 to $120 \mathrm{~min}$ after the commencement of a glucose infusion via the contralateral cannula. The dose of D-Lys3-GHRP-6 was determined according to several reports (Fujino et al. 2003, Dezaki et al. 2004, Dong et al. 2006). The control group received saline vehicle alone. In order to determine physiological effects of ghrelin as far as possible, we avoided administering ghrelin to the fasting animals in which plasma ghrelin levels had reached plateau $(2 \cdot 0 \mathrm{ng} / \mathrm{ml})$.

In Experiment 2, HGC was conducted in all groups from 3 to $8 \mathrm{~h}$ after feeding (meal-fed state) when plasma ghrelin levels were nadir (Sugino et al. 2002). Concomitantly, two ghrelintreated groups received synthetic ovine ghrelin (Peptide Institute Inc., Osaka, Japan) in saline $(0 \cdot 9 \% \mathrm{NaCl}, 0 \cdot 1 \%$ sheep serum albumin) at a rate of $0.04 \mu \mathrm{g} / \mathrm{kg}$ body weight per min through the left jugular cannula. The control group received saline vehicle alone. The ghrelin plus antagonist-treated group received a total dose of $70 \mathrm{nmol} / \mathrm{kg}$ body weight DLys3-GHRP-6 in normal saline (or saline vehicle alone) via the right jugular cannula every $60 \mathrm{~min}$ from 0 to $120 \mathrm{~min}$ after the commencement of a glucose infusion via the contralateral cannula. In order to determine physiological effects of ghrelin as far as possible, we avoided administering the antagonist alone to the fed animals in which plasma ghrelin levels had reached nadir $(0.5 \mathrm{ng} / \mathrm{ml})$.

Blood samples were collected through the right cannula, immediately placed into a heparinized tube with aprotinin $\left(1000 \mathrm{KIU} / \mathrm{ml}\right.$ of blood) and centrifuged for $10 \mathrm{~min}$ at $4{ }^{\circ} \mathrm{C}$. Harvested plasma was stored at $-80^{\circ} \mathrm{C}$ until assay.

\section{Hyperglycemic clamp}

The HGC technique was used to determine insulin responsiveness to glucose. Glucose solution was prepared at
$20 \%$ (wt/vol). Basal glucose concentrations were determined three times at 10-min interval before glucose infusion. In the HGC, blood glucose levels were raised to the desired hyperglycemia $(100 \mathrm{mg} / 100 \mathrm{ml}$ higher than the basal blood glucose) and were maintained at that plateau by infusing the glucose solution via the right cannula with a peristaltic pump (Mode AC-2120, Atto Co. Ltd, Tokyo, Japan). Blood glucose levels were measured with a glucose analyzer (GLU-1, TOA Electronics Ltd, Tokyo, Japan) at 5-min intervals throughout the experiment, and glucose infusion rate was empirically determined.

Time-resolved fluoro-immunoassay of plasma ghrelin, insulin, and $\mathrm{GH}$

Ghrelin An assay for bioactive ghrelin was done as described previously (Sugino et al. 2002). The ghrelin concentration was measured by competitive solid-phase immunoassay using Europium (Eu)-labeled synthetic rat ghrelin and polystyrene microtiter strips (Nalge Nunc Int., Tokyo, Japan) coated with anti-rabbit $\gamma$-globulin. Intra- and inter-assay coefficients of variation were 6.9 and $5.5 \%$ respectively. Least detectable dose and IC50 in this assay system were 0.025 and $0 \cdot 831 \mathrm{ng} / \mathrm{ml}$ respectively.

Insulin Insulin assay was done as described previously (Takahashi et al. 2006). The insulin concentration was measured by competitive solid-phase immunoassay using Europium (Eu)labeled synthetic bovine insulin and polystyrene microtiter strips (Nalge Nunc Int.) coated with anti-guinea pig $\gamma$-globulin. The anti-human insulin was kindly supplied by Dr. K. Wakabayashi (Biosignal Research Center, Institute for Molecular and Cellular Regulation, Gunma University). Intra- and inter-assay coefficients of variation were $3 \cdot 2$ and $3 \cdot 1 \%$ respectively. Least detectable dose and IC50 in this assay system were 0.016 and $1 \cdot 073 \mathrm{ng} / \mathrm{ml}$ respectively.

GH GH assay was done as described previously (Sugino et al. 2002). The GH concentration was measured by competitive solid-phase immunoassay using Europium (Eu)-labeled synthetic ovine GH and polystyrene microtiter strips (Nalge Nunc Int.) coated with anti-rabbit $\gamma$-globulin. Intra- and inter-assay coefficients of variation were $4 \cdot 1$ and $9 \cdot 3 \%$ respectively. Least detectable dose and IC50 in this assay system were 0.158 and $8.738 \mathrm{ng} / \mathrm{ml}$ respectively.

\section{Statistical analysis}

The values of plasma ghrelin, insulin and GH concentrations, and glucose infusion rates were expressed as means \pm s.E.M. Repeated measures of two-way ANOVA was used to evaluate statistical significance of treatment effects on each parameter over time. Statistical comparisons for glucose, ghrelin, GH and insulin among the treatments at each time point was evaluated using the post hoc Fisher's test. 


\section{Results}

In the HGC (Experiments 1 and 2), plasma glucose concentrations were clamped at $100 \mathrm{mg} / 100 \mathrm{ml}$ above the initial level between 60 and $300 \mathrm{~min}$ after the start of glucose infusion (Figs 1a and 3a). There was no difference in basal plasma glucose concentrations before glucose infusion between the fasting (Fig. 1a) and meal-fed state (Fig. 3a).

In the fasting state (Experiment 1), average plasma ghrelin level was $1.8 \mathrm{ng} / \mathrm{ml}$ before glucose infusion (Fig. 1b). Plasma ghrelin levels were significantly $(P<0 \cdot 01)$ decreased after the commencement of glucose infusion in both groups (Fig. 1b). Plasma GH levels were significantly $(P<0 \cdot 05)$ increased after glucose infusion in both groups (Fig. 1c). Plasma ghrelin and $\mathrm{GH}$ levels were not affected by the ghrelin antagonist (Fig. 1b and c).

Changes in plasma insulin levels in the fasting state are presented in Fig. 2. Plasma insulin levels were significantly $(P<0 \cdot 01)$ increased by glucose infusion in both groups. There was a greater incremental increase $(P<0 \cdot 01)$ in plasma insulin concentrations in the D-Lys3-GHRP6 group when compared with the control beginning about 60 min after the third administration of the antagonist.

In the meal-fed state (Experiment 2), average plasma ghrelin level was $0.5 \mathrm{ng} / \mathrm{ml}$ before glucose infusion (Fig. 3b). Plasma ghrelin levels significantly $(P<0 \cdot 01)$ increased and reached a plateau within $10 \mathrm{~min}$ after the commencement of ghrelin

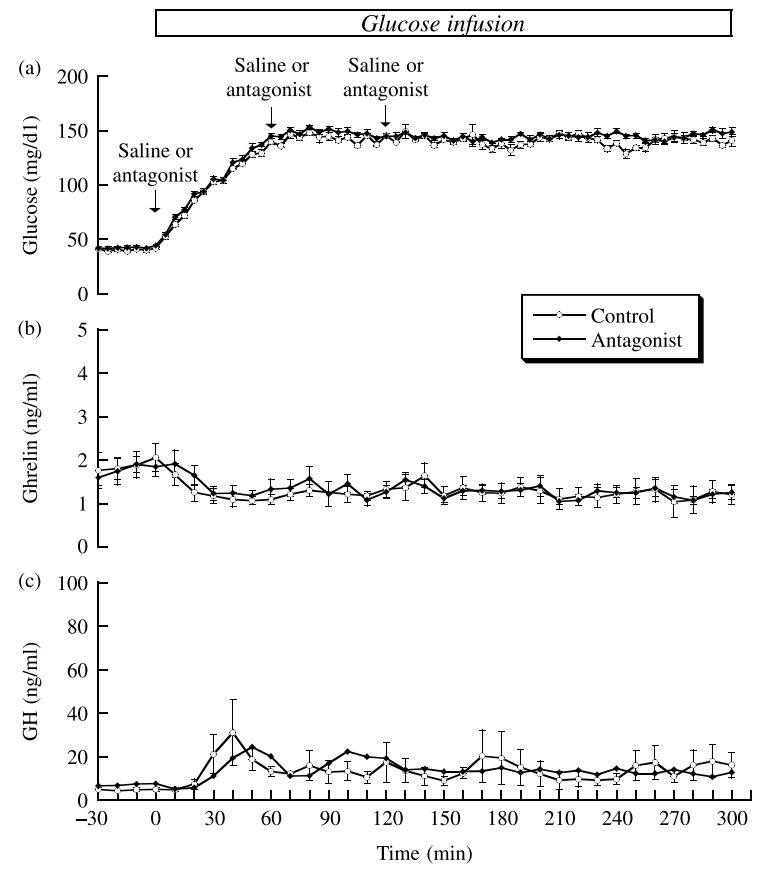

Figure 1 (a) Average glucose, (b) ghrelin, and (c) $\mathrm{GH}$ plasma concentrations in fasted sheep receiving saline (control) or D-lys3-GHRP-6 (antagonist, total dose of $70 \mathrm{nmol} / \mathrm{kg}$ body weight) every 60 min during the first half of hyperglycemic clamp.Values are means \pm S.E.M. $(n=4)$.

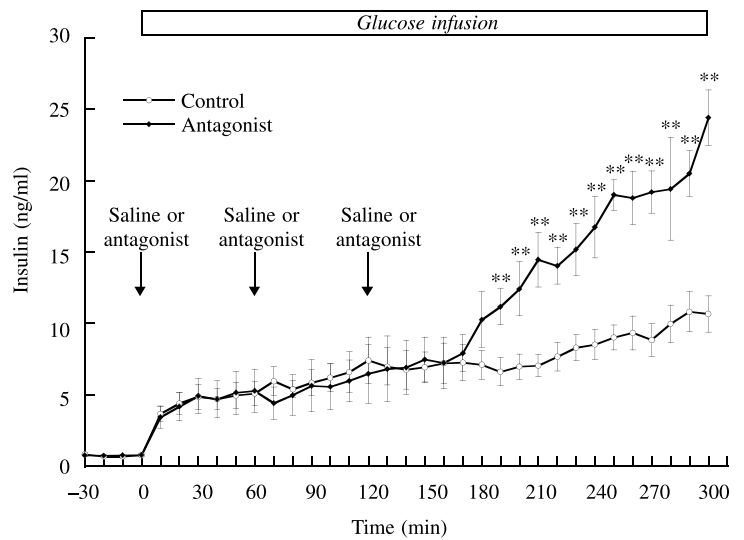

Figure 2 Average insulin plasma concentrations in fasted sheep receiving saline (control) or D-lys3-GHRP-6 (antagonist, total dose of $70 \mathrm{nmol} / \mathrm{kg}$ body weight) every $60 \mathrm{~min}$ during the first half of hyperglycemic clamp.Values are means \pm s.E.M. $(n=4) .{ }^{* *} P<0 \cdot 01$ versus control.

infusion (Fig. 3b). There were temporal increases $(P<0 \cdot 05)$ in plasma GH levels during ghrelin infusion (Fig. 3c). Increase in plasma GH levels was significantly $(P<0 \cdot 01)$ depressed by the ghrelin antagonist between the first- and second administration of the ghrelin antagonist (Fig. 3c).
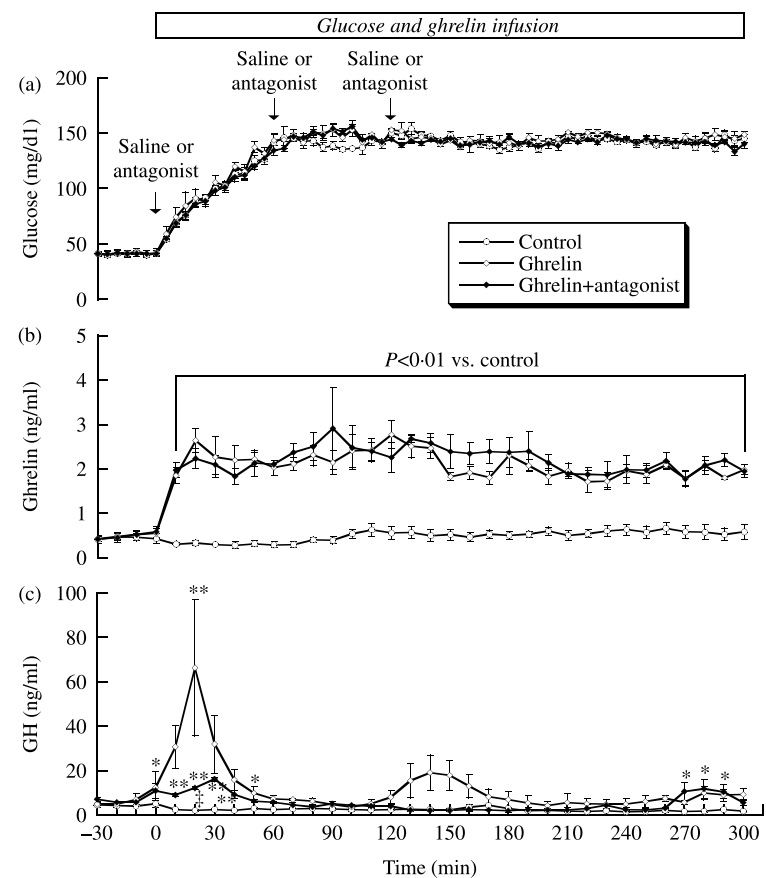

Figure 3 (a) Average glucose, (b) ghrelin, and (c) GH plasma concentrations in meal-fed sheep continuously receiving saline (control) or ghrelin (ghrelin, $0 \cdot 04 \mu \mathrm{g} / \mathrm{kg}$ body weight per min) during hyperglycemic clamp. Saline vehicle or D-lys3-GHRP-6 (antagonist, total dose of $70 \mathrm{nmol} / \mathrm{kg}$ body weight) was administered every $60 \mathrm{~min}$ during the first half of hyperglycemic clamp. Values are means \pm S.E.M. $(n=4) .{ }^{*} P<0.05$ versus control, ${ }^{* *} P<0.01$ versus control, ${ }^{\ddagger} P<0 \cdot 01$ versus ghrelin. 


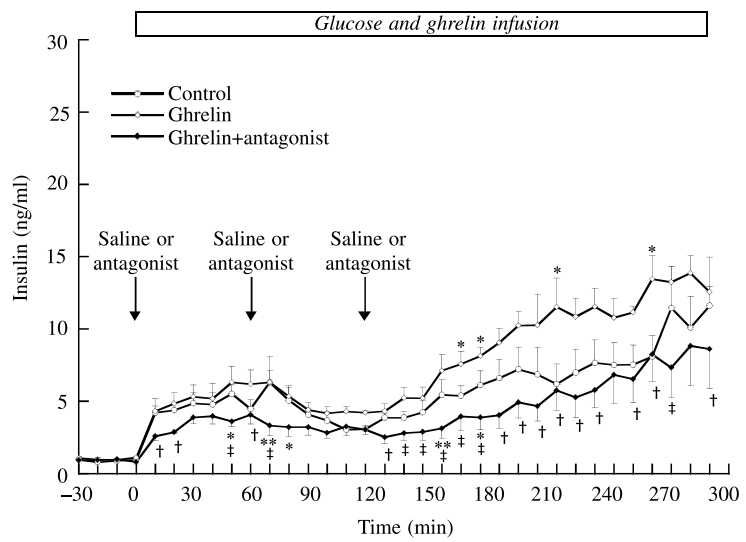

Figure 4 Average insulin plasma concentrations in meal-fed sheep continuously receiving saline (control) or ghrelin (ghrelin, $0.04 \mu \mathrm{g} / \mathrm{kg}$ body weight per min) during hyperglycemic clamp. Saline vehicle or D-lys3-GHRP-6 (antagonist, total dose of $70 \mathrm{nmol} / \mathrm{kg}$ body weight) was administered every $60 \mathrm{~min}$ during the first half of hyperglycemic clamp. Values are means \pm s.E.M. $(n=4)$. ${ }^{*} P<0.05$ versus control, ${ }^{* *} P<0.01$ versus control, ${ }^{\dagger} P<0.05$ versus ghrelin, ${ }^{\ddagger} P<0 \cdot 01$ versus ghrelin.

Changes in plasma insulin levels in the meal-fed state are presented in Fig. 4. Plasma insulin levels were significantly $(P<0 \cdot 01)$ increased by glucose infusion in all groups. There was a biphasic insulin increment in control and ghrelininfused group. Ghrelin significantly $(P<0 \cdot 05)$ enhanced only the second phase of insulin secretion. The ghrelin antagonist significantly $(P<0 \cdot 05)$ depressed both the first- and second phase of insulin secretion.

\section{Discussion}

Effects of ghrelin on insulin secretion are bi-directional, since ghrelin exerts both stimulatory and inhibitory effects on insulin secretion. Ghrelin inhibits insulin secretion in fasted humans (Broglio et al. 2001) and mice (Reimer et al. 2003). By contrast, i.v. injection of ghrelin accelerates insulin secretion in free-feeding rats (Lee et al. 2002) and fed sheep (Takahashi et al. 2006). Ghrelin stimulates insulin secretion from isolated pancreatic islets of freely fed rats (Date et al. 2002). Taken together, these reports suggest that ghrelin differentially modulates insulin secretion, dependent on feeding states. The present study has clearly demonstrated that ghrelin inhibits and stimulates glucose-induced insulin secretion in fasting- and meal-fed state respectively.

Baseline of plasma ghrelin fluctuates between 0.5 and $2 \cdot 0 \mathrm{ng} / \mathrm{ml}$ depending on the feeding states in sheep. The fluctuation of plasma ghrelin makes it difficult for us to determine the effects of ghrelin, since it is uncertain which level of plasma ghrelin is most effective on insulin secretion in different feeding states. In order to determine physiological effects of ghrelin as far as possible, we avoided administering ghrelin to the fasting animals in which plasma ghrelin levels had reached plateau $(2 \cdot 0 \mathrm{ng} / \mathrm{ml})$, while we did not administer the ghrelin antagonist alone to the fed animals in which plasma ghrelin levels had reached nadir $(0.5 \mathrm{ng} / \mathrm{ml})$. Our previous study showed that ghrelin significantly enhanced glucose-stimulated insulin secretion at $1.0 \mathrm{ng} / \mathrm{ml}$ of plasma level in the meal-fed state (Takahashi et al. 2006). Therefore, the effect of the antagonist on insulin response at plasma ghrelin levels between 1.0 and $1.5 \mathrm{ng} / \mathrm{ml}$ during the HGC in the fasting states would be comparable with the effect of ghrelin administration in the meal-fed state.

In the meal-fed state, exogenous ghrelin enhanced glucoseinduced insulin secretion as shown previously (Takahashi et al. 2006). The enhancement by ghrelin of glucose-stimulated insulin secretion was delayed in the present study when compared with the previous study. This may be related to weak insulin response to glucose in the animals newly applied to the HGC. Repeated doses of a ghrelin antagonist, D-Lys3GHRP-6, counteracted the stimulatory effect of exogenous ghrelin on insulin secretion, suggesting that ghrelin stimulates insulin secretion via GHS-R1a in the meal-fed state. In addition, even lower insulin secretion by ghrelin plus antagonist compared with control suggests the possibility that basal ghrelin in the meal-fed state may also enhance insulin secretion.

In the fasting state, repeated doses of D-Lys3-GHRP-6 significantly enhanced glucose-induced insulin release, suggesting that endogenous ghrelin suppresses insulin secretion in the fasting state. The present result is supported by the finding that GHS-R antagonist enhances glucoseinduced insulin release from perfused rat pancreas and increases plasma insulin levels in rats (Dezaki et al. 2006). In the present study, the insulin secretory response to the ghrelin antagonist emerged $60 \mathrm{~min}$ after the last dose of the drug. The hypoglycemic effect of the ghrelin antagonist emerges 2 days after the commencement of daily injections in diabetic mice where plasma ghrelin levels are high (Dong et al. 2006). In the fasting state, therefore, high levels of circulating ghrelin might compete with the ghrelin antagonist for GHS receptors, thus delaying the action of the drug.

Ghrelin stimulates GH secretion in sheep (Iqbal et al. 2006, Takahashi et al. 2006). In the present study, therefore, plasma $\mathrm{GH}$ concentrations were measured as an indicator for ghrelin receptor blockade. In the fed-state, D-Lys3-GHRP-6 attenuated ghrelin-induced GH secretion, indicating that the antagonist certainly blocked the ghrelin receptors. In the fasting state, however, the antagonist did not affect GH secretion, probably because GHS-R1a might not be involved in $\mathrm{GH}$ elevation after glucose infusion. Furthermore, ghrelin receptor mRNA expression is upregulated by fasting in the hypothalamus and pituitary (Kim et al. 2003). This may be related to the ineffectiveness of the ghrelin antagonist in $\mathrm{GH}$ suppression in the fasting state.

In conclusion, ghrelin inhibits and stimulates glucoseinduced insulin secretion via GHS-R1a in fasting- and mealfed state respectively. Further studies are required to identify 
underlying mechanisms for alteration in the effects of ghrelin on insulin secretion in different feeding states.

\section{Acknowledgements}

We are grateful to Kenji Kanayama, Atsushi Gushiken, Hiromi Manabe, Naoya Mori, and Yuki Oshiba for their excellent help in performing this study. The authors are grateful to Professor Iain Clarke of Monash University, Department of Physiology for his kind advice on the manuscript. This study was partially supported by funding from the High Technology Research Center Development Program of the Ministry of Education, Culture, Sports, Science and Technology, Japan. There is no conflict of interest that would prejudice the impartiality of this study.

\section{References}

Adeghate E \& Ponery AS 2002 Ghrelin stimulates insulin secretion from the pancreas of normal and diabetic rats. Journal of Neuroendocrinology 14 555-560.

Ariyasu H, Takaya K, Tagami T, Ogawa Y, Hosoda K, Akamizu T, Suda M, Koh T, Natsui K, Toyooka S et al. 2001 Stomach is a major source of circulating ghrelin, and feeding state determines plasma ghrelin-like immunoreactivity levels in humans. Journal of Clinical Endocrinology and Metabolism 86 4753-4758.

Broglio F, Arvat E, Benso A, Gottero C, Muccioli G, Papotti M, van der Lely AJ, Deghenghi R \& Chigo E 2001 Ghrelin, a natural GH secretagogue produced by the stomach, induces hyperglycemia and reduces insulin secretion in humans. Journal of Clinical Endocrinology and Metabolism $\mathbf{8 6}$ 5083-5086.

Colombo M, Gregersen S, Xiao J \& Hermansen K 2003 Effects of Ghrelin and other neuropeptides (CART, MCTH, Orexin A and B, and GLP-1) on the release of insulin from isolated rat islets. Pancreas 27 161-166.

Cummings DE, Purnell JQ, Frayo RS, Schmidova K, Wisse BE \& Weigle DS 2001 A preprandial rise in plasma ghrelin levels suggests a role in meal initiation in humans. Diabetes 50 1714-1719.

Date Y, Nakazato M, Hashiguchi S, Dezaki K, Mondal MS, Hosoda H, Kojima M, Kangawa K, Arima T, Matsuo H et al. 2002 Ghrelin is present in pancreatic alpha-cells of humans and rats and stimulates insulin secretion. Diabetes $\mathbf{5 1}$ 124-129.

Dezaki K, Hosoda H, Kakei M, Hashiguchi S, Watanabe M, Kangawa K \& Yada T 2004 Endogenous ghrelin in pancreatic islets restricts insulin release by attenuating $\mathrm{Ca}^{2+}$ signaling in B-cells. Diabetes 53 3142-3151.

Dezaki K, Sone H, Koizumi M, Nakata M, Kakei M, Nagai H, Hosoda H, Kangawa K \& Yada T 2006 Blockade of pancreatic islet-derived ghrelin enhances insulin secretion to prevent high-fat diet-induced glucose intolerance. Diabetes 55 3486-3493.
Dong J, Peeters TL, De Smet B, Moechars D, Delporte C, Vanden Berghe P, Coulie B, Tang M \& Depoortere I 2006 Role of endogenous ghrelin in the hyperphagia of mice with streptozotocin-induced diabetes. Endocrinology 147 2634-2642.

Fujino K, Inui A, Asakawa A, Kihara N, Fujimura M \& Fujimiya M 2003 Ghrelin induces fasted motor activity of the gastrointestinal tract in conscious fed rats. Journal of Physiology $550227-240$.

Iqbal J, Kurose Y, Canny B \& Clarke IJ 2006 Effects of central infusion of ghrelin on food intake and plasma levels of growth hormone, luteinizing hormone, prolactin, and cortisol secretion in sheep. Endocrinology 147 510-519.

Kim MS, Yoon CY, Park KH, Shin CS, Park KS, Kim SY, Cho BY \& Lee HK 2003 Changes in ghrelin and ghrelin receptor expression according to feeding status. Neuroreport 14 1317-1320.

Kojima M, Hosoda H, Date Y, Nakazato M, Matuo H \& Kangawa K 1999 Ghrelin is a growth-hormone-releasing acylated peptide from stomach. Nature 402 656-660.

Lee HM, Wang G, Englander EW, Kojima M \& Greeley GH, Jr 2002 Ghrelin, a new gastrointestinal endocrine peptide that stimulates insulin secretion: enteric distribution, ontogeny, influence of endocrine, and dietary manipulations. Endocrinology 143 185-190.

Nakazato M, Murakami N, Date Y, Kojima M, Matsuo H, Kangawa K \& Matsukura S 2001 A role for ghrelin in the central regulation of feeding. Nature 409 194-198.

Reimer MK, Pacini G \& Ahren B 2003 Dose-dependent inhibition by ghrelin of insulin secretion in the mouse. Endocrinology 144 916-921.

Shiiya T, Nakazato M, Mizuta M, Date Y, Mondal MS, Tanaka M, Nozone S, Hosoda H, Kangawa K \& Matsukura S 2002 Plasma ghrelin levels in lean and obese humans and the effect of glucose on ghrelin secretion. Journal of Clinical Endocrinology and Metabolism 87 240-244.

Sugino T, Hasegawa Y, Kikkawa Y, Yamaura J, Yamagishi M, Kurose Y, Kojima M, Kangawa K \& Terashima Y 2002 A transient ghrelin surge occurs just before feeding in scheduled meal-fed sheep. Biochemical and Biophysical Research Communications 295 255-260.

Takahashi H, Kurose Y, Kobayashi S, Sugino T, Kojima M, Kangawa K, Hasegawa Y \& Terashima Y 2006 Ghrelin enhances glucose-induced insulin secretion in scheduled meal-fed sheep. Journal of Endocrinology 189 83-91.

Takaya K, Ariyasu H, Kanamoto N, Iwakura H, Yoshimoto A, Harada M, Mori K, Komatsu Y, Usui T, Shimatsu A et al. 2000 Ghrelin strongly stimulates growth hormone release in humans. Journal of Clinical Endocrinology and Metabolism 85 4908-4911.

Tschop M, Smiley DL \& Heiman ML 2000 Ghrelin induces adiposity in rodents. Nature 407 908-913.

Wren AM, Seal LJ, Cohen MA, Brynes AE, Frost GS, Murphy KG, Dhillo WS, Ghatei MA \& Bloom SR 2001 Ghrelin enhances appetite and increases food intake in humans. Journal of Clinical Endocrinology and Metabolism 86 5992-5995.

Received in final form 26 June 2007

Accepted 28 June 2007

Made available online as an Accepted Preprint 4 July 2007 